\title{
Trabeculae In The Egretal (Egretta garzetta) Cervical Vertebrae
}

\author{
Faris Choirudin*, Kholifah Nyawiji, Wahyu Priyambodo \\ Biology Education Department, Faculty of Sains and Technology, UIN Sunan Kalijaga \\ Jl. Marsda Adisucipto No 1 Yogyakarta 55281, Indonesia. Tel. +62-274-540971, Fax. +62-274-519739 \\ Email*: fariischdn@gmail.com
}

\begin{abstract}
The egretta bird (Egretta zegretta) has a body size of 55-65 centimeters, it is wings stretches 88-106 centimeters, has a long neck and typical neck like the letter "S". The purpose of this research is to find out the anatomical structure of trabeculae in the egretta bird. To find out the trebeculae in the egretta bird, meat on the neck cleaned. Then, each bone segment is cut and sanded on the ventral and lateral part until spongiosa tissue (trabeculae) is seen, and transversely cut. The observation result show that on the C6 bone segment has a trabecular structure more dense comepared to the structure of the trabelucae in other bone segments. That is because in the C6 bone segment gets pressure from top and bottom, so C6 bone segment stronger.
\end{abstract}

Keywords: Egretta bird, trabeculae, Cervical Vertebrae

\section{INTRODUCTION}

Egret (Egretta garzetta) is one type of water bird which is part of it is life are in water areas or wetlands (Elvidasari \& Jumardi, 2005). Egret included in the order Ciconiiformes and the Ardeidae family that widespread around the world including Indonesia, in Sumatera, Kalimantan, and Bali (MacKinnon, 2010). From 24 species of the Ardeidae spesies, half of them protected according to government regulations number 7 of 1999 , about Preserving Plant and Animal Species. The egret (Egretta garzetta) has a body size of 55-65 centimeters; it is wings stretches $88-106$ centimeters. The egret has a white fur, black beak, long black legs, and yellow or black toes (Sudarsana, 2006). Besides having long legs, egret also has a long neck for it is survival (animal food). Ardeidae was very careful in chasing or follwowing their prey. While standing waiting for prey, neck in a resting position (form the letter S). When flying, S-shaped neck are not straightened (Grzimek, 1972).
Egret has a highly adapted body skeleton for flight. The body skeleton very light but quite strong for withstand the pressure at take off, fly, and landing. Egret is a bird that flies by flying or soaring, tend to have more hollow bones (Ritchison, 2007).

\section{METHOD}

This research-using egret (Egretta garzetta) as an object to study. Cervical vertebrae separated from it is body. To determine the anatomical structure of the trabeculae in egret's cervical vertebrae, tissue on the egret's neck is cleaned, then each bone segment is cut and sanded until spongiosa (trabeculae) is seen, and transversely cut. The data that obtained is a picture of trabeculae structure on $\mathrm{C} 2, \mathrm{C} 6$, and $\mathrm{C} 12$ bone segments. Then the picture is analyzed to get the anatomical structure of the cervical vertebrae.

RESULT

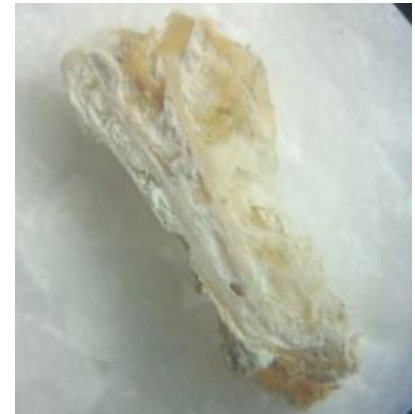

(i)

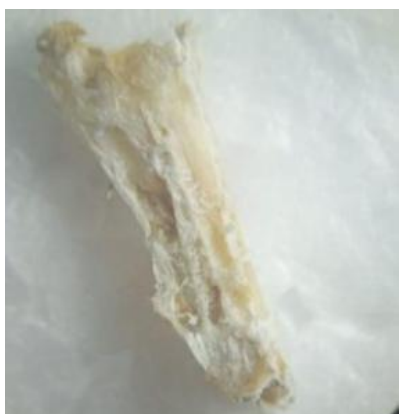

(ii)

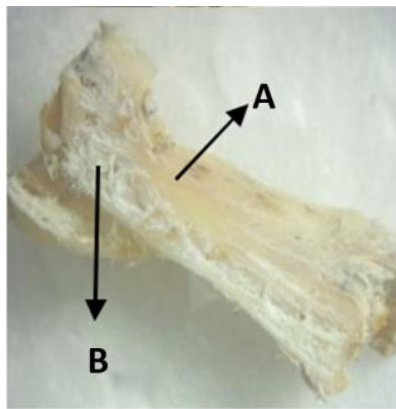

(iii)

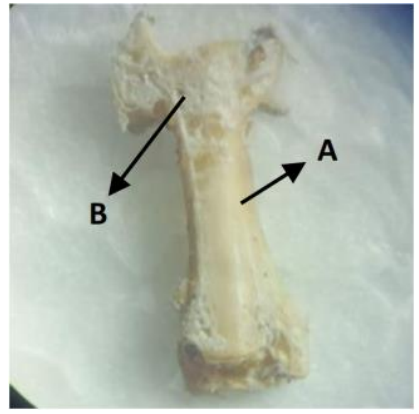

(iv)

Figure 1. (i) Trabecular structure of the ventral C2 segment in the egret's cervical vertebrae. A) Cortical, B) Trabeculae. Magnification: $0.8 X$. (ii) Trabecular structure of the lateral C2 segment in the egret's cervical vertebrae. A) Cortical, B) Trabeculae. Magnification: 0.8X. (iii) Trabecular structure of the ventral C6 segment in the egret's cervical vertebrae. A) Cortical, B) Trabeculae. Magnification: 0.8X. (iv) Trabecular structure of the lateral C6 segment in the egret's cervical vertebrae. A) Cortical, B) Trabeculae. Magnification: $0.8 \mathrm{X}$. 


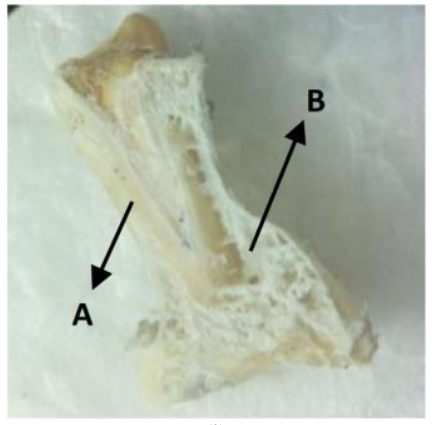

(i)

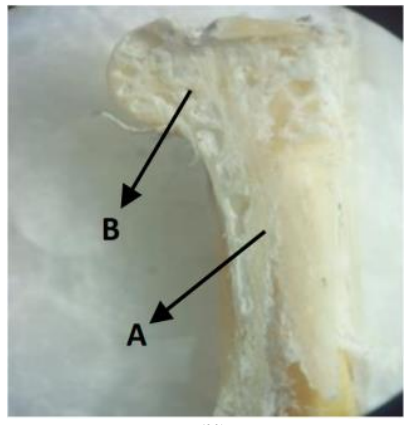

(ii)

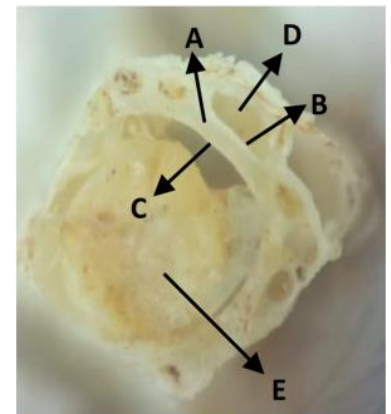

(iii)

Figure 2. (i) Trabecular structure of the ventral C12 segment in the egret's cervical vertebrae. A) Cortical, B) Trabeculae. Magnification: 0.8X. (ii) Trabecular structure of the lateral C12 segment in the egret's cervical vertebrae. A) Cortical, B) Trabeculae. Magnification: $0.8 X$. (iii) Cross section of C12 bone segment. A) Cortical, B) Periosteal, C) Endosteal, D) Trabeculae, E) Marrow. Magnification: 0.8X

\section{DISCUSSIONS}

There are two parts of bone, cortical bone and trabeculae. Cortical bone is solid and strong bones that surround the bone marrow space. Trabeculae is bone composed of tissue like beehive. In the cortical bone, there is an outer surface (periosteal) and inner suface (endosteal). Periosteal is a fibrous connective tissue sheath, which surrounds the outer surface of cortical bone, except joints where the bone is bonded by articular cartilage. Endosteal is a membrane structure that surrounds the inner surface of cortical bone and canal vessels in the bones (Kini \& Nadeesh, 2012).

Trabeculae in the cervical vertebrae of egrets have a unique structure. There are a cavities that piled up and irregular. The trabeculae are along the bone segment and arround the bone marrow.

Based on the result of observation, it's known that the structure of the trabeculae in the $\mathrm{C} 2$ and $\mathrm{C} 12$ bone segment there are more cavities compared with the structure of the trabeculae in the C6 bone segment. It's strengthened by Ritchison (2007) which states that egret is a bird that flies by flying or soaring, tend to have more hollow bones.

C6 bone segment is the point where bone segments are deflected from above meets with bone segments are deflected from below. Thus give pressure from the top and bottom of the bone segment.

\section{CONCLUSION}

Based on the observations, can be concluded that there are two part of bones, cortical and trabeculae. The trabeculae located after the marrow and cortical. The structure of the trabeculae on the egret has a difference.
On the $\mathrm{C} 2$ and $\mathrm{C} 12$ bone segment, trabecular structure more cavities compared with the trabecular structure on the $\mathrm{C} 6$ bone segment. The trabeculae on the C6 bone segment more dense because the segment is under pressure from top and bottom. Thus make the C6 bone segment more strong and dense compared with the other bone segment.

\section{REFERENCES}

Elfidasari, D., 2005. Pengaruh Perbedaan Lokasi Mencari Makan Terhadap Keragaman Mangsa Tiga Jenis Kuntul di Cagar Alam Pulau Dua Serang: Casmerodius albus, Egretta garzetta, Bubulcus ibis., Makara Sains 9(1) : 7-12

Grzimek, B. 1972. Anima Life Ancylopedia. Bird II (8), Van nostrand Reinhold Co., New York-Cincinnaati-TorontoMelbourne.

Mackinnon, J., Karen, P. \& Bas Van Balen. 2000. BurungBurung di Sumatera, Jawa, Bali dan Kalimantan. Lembaga Ilmu Pengetahuan Indonesia. Bogor.

Ritchison, Gary. 2007. Ornithology (Bio 554/754): Bird Respiratory System). Eastern Kentucky University.

Sudarsana, I.W. 2006. Perilaku Makan Burung Kuntul Kecil (Egretta garzetta) di The Mangrove Information Centre Suwung Denpasar Bali. Jurusan Biologi Fakultas Matematika dan Ilmu Pengetahuan Alam. Universitas Udayana, Bali. 